\title{
Reply to: Effects of partly supervised and home-based exercise program in patients undergoing hematopoietic stem cell transplantation: a case-control study
}

\author{
L. Nogueira ${ }^{1}(\mathbb{D}) \cdot A B$. Blazina ${ }^{1}$
}

Received: 15 May 2020 / Accepted: 13 June 2020 / Published online: 17 June 2020

(C) Springer-Verlag GmbH Germany, part of Springer Nature 2020

Dear Editor,

We read with great interest the case-control study by Yildiz Kabak et al. regarding home exercise in patients undergoing hematopoietic stem cell transplantation [1]. Although the limitations are presented by the authors, the effects related to exercise in quality of life and in the treatment of patients undergoing hematopoietic stem cell transplantations are extremely relevant to this population that keep growing worldwide [2].

However, the case-control study reported in the article has changed its original design at the moment of selection of participants and by performing an intervention. A case-control study is an observational study, usually retrospective, in whose participants are chosen due their outcomes and separated by exposition [3], in which the final objective is to identify an odds ratio relating exposure with outcome [4]. Yildiz Kabak et al.'s research aimed to determine the effectiveness of an individual exercise program by starting before hematopoietic stem cell transplantation and continued with home exercise program after discharge up to 100 days after transplantation. Being a prospective study, with an intervention group and without information about randomization, it seems to us that this research fits better as a prospective, controlled study [5].

Sincerely,

Laura Nogueira, B.Sc

Andrya Blazina, B.sc

LJ. Nogueira

laurajnogueira@gmail.com

1 Institute of Cardiology/University Foundation of Cardiology, Porto Alegre, Rio Grande do Sul, Brazil
Institute of Cardiology, University Foundation of Cardiology, Porto Alegre, Rio Grande do Sul, Brazil

\section{Compliance with ethical standards}

Conflict of interest The authors declare that they have no conflict of interest.

\section{References}

1. Yildiz Kabak V, Goker H, Duger T (2020) Effects of partly supervised and home-base exercise program in patients undergoing hematopoietic stem cell transplantation: a case-control study. Support Care Cancer. https://doi.org/10.1007/s00520-020-05432-x

2. Niederwieser D, Baldomero H, Szer J et al (2016) Hematopoietic stem cell transplantation activity worldwide in 2012 and a SWOT analysis of the worldwide network for blood and marrow transplantation group including the global survey. Bone Marrow Transplant 51:778-785. https://doi.org/10.1038/bmt.2016.18

3. Dupépé EB, Kicielinski KP, Gordon AS, Walters BC (2019) What is a case-control study? Neurosurgery $184(4): 819-826$. https://doi.org/ 10.1093 /neuros/nyy590

4. Herbert R (2017) Case-control studies. Aust J Phys 63(4):264-266. https://doi.org/10.1016/j.jphys.2017.08.007

5. Chidambaram AG, Josephson M (2019) Clinical research study designs: the essentials. Pediatr Investig 3:245-252. https://doi.org/10. $1002 /$ ped4.12166

Publisher's note Springer Nature remains neutral with regard to jurisdictional claims in published maps and institutional affiliations. 